\title{
Corrigendum to "Angiogenesis in Pituitary Adenomas: Human Studies and New Mutant Mouse Models"
}

\author{
Carolina Cristina (D), ${ }^{1,2}$ Guillermina María Luque $\mathbb{D D}^{1}{ }^{1}$ Gianina Demarchi, ${ }^{2}$ \\ Felicitas Lopez Vicchi, ${ }^{1}$ Lautaro Zubeldia-Brenner ${ }^{(D},{ }^{1}$ Maria Ines Perez Millan, ${ }^{1}$ \\ Sofia Perrone, ${ }^{2}$ Ana Maria Ornstein, ${ }^{1}$ Isabel M. Lacau-Mengido $\mathbb{D}^{1},{ }^{1}$ Silvia Inés Berner, ${ }^{3,4}$ \\ and Damasia Becu-Villalobos ${ }^{1}$ \\ ${ }^{1}$ Instituto de Biología y Medicina Experimental, CONICET, Vuelta de Obligado 2490, 1428 Buenos Aires, Argentina \\ ${ }^{2}$ CITNOBA (CONICET-UNNOBA), Universidad Nacional del Noroeste de la Provincia de Buenos Aires, Monteagudo 2772, \\ Pergamino, 2700 Buenos Aires, Argentina \\ ${ }^{3}$ Servicio de Neurocirugía, Clínica Santa Isabel, Avenida Directorio 2037, C1406GZJ Buenos Aires, Argentina \\ ${ }^{4}$ Servicio de Neurocirugía, Hospital Santa Lucía, Avenida San Juan 2021, C1232AAC Buenos Aires, Argentina
}

Correspondence should be addressed to Damasia Becu-Villalobos; damabecu@gmail.com

Received 30 June 2020; Accepted 30 June 2020; Published 18 July 2020

Copyright ( $\odot 2020$ Carolina Cristina et al. This is an open access article distributed under the Creative Commons Attribution License, which permits unrestricted use, distribution, and reproduction in any medium, provided the original work is properly cited.

The article titled "Angiogenesis in Pituitary Adenomas: Human Studies and New Mutant Mouse Models" [1] reused wording from a book chapter published the same year by the same author group, "Prolactinomas: Role of VEGF, FGF-2 and CD31" in Tumors of the Central Nervous System [2], which was not cited. The review brought together the results of the authors' previous experimental work on angiogenesis and pituitary adenomas in the context of the literature.

\section{References}

[1] C. Cristina, G. María Luque, G. Demarchi et al., “Angiogenesis in pituitary adenomas: human studies and new mutant mouse models," International Journal of Endocrinology, vol. 2014, Article ID 608497, 11 pages, 2014.

[2] M. Ines, M. Perez, C. Cristina, S. Inés Berner, and D. BecuVillalobos, "Prolactinomas: role of VEGF, FGF-2 and CD31," in Tumors of the Central Nervous System, M. A. Hayat, Ed., vol. 12, pp. 33-41, Springer Science+Business Media, Dordrecht, Netherlands, 2014. 